\title{
MODEL ADVANCED ORGANIZER: PENGARUHNYA TERHADAP KEMAMPUAN BERPIKIR KREATIF
}

\section{ADVANCED ORGANIZER MODEL: THE EFFECT ON CREATIVE THINKING ABILITY}

\author{
Listia Ernaeni ${ }^{1}$, Indra Gunawan ${ }^{2}$ \\ 1,2Prodi Pendidikan Fisika Fakultas Tarbiyah dan Keguruan Universitas Islam Negeri Raden Intan Lampung \\ e-mail : listiaernaeni@gmail.com
}

Diterima: 2Februari 2019. Disetujui: 25 Februari 2019. Dipublikasikan: 29 Maret 2019

\begin{abstract}
This study uses the type of Quasy Experiment Design with the design of Non Equivalent Control Group Design. The study used two classes as the experimental class and the control class. The study population was VII grade students. The sampling technique used is Cluster Random Sampling. Based on data analysis and discussion, there are differences in the average value of learning outcomes (posttest) between learning using the advanced organizer and conventional learning models, from the results of the t test also known that $0.044<0.05$ which means $H O$ is rejected which indicates the influence of the model advanced organizer learning on students' creative thinking abilities.
\end{abstract}

Keywords: advanced organizer, learning model, creative thinking ability

\begin{abstract}
Abstrak: Penelitian ini menggunakan jenis Quasy Eksperiment Design dengan rancangan desain Non Equivalent Control Group Design. Penelitian menggunakan dua kelas sebagai kelas eksperimen dan kelas kontrol.. Populasi penelitian adalah peserta didik kelas VII. Teknik pengambilan sampel yang digunakan dengan cara Cluster Random Sampling. Berdasarkan analisis data dan pembahasan, terdapat perbedaan nilai rata-rata hasil belajar (postest) antara pembelajaran dengan menggunakan model pembelajaran advanced organizer dan konvensional, dari hasil perhitungan uji t juga diketahui bahwa $0,044<0,05$ yang berarti $\mathrm{H}_{0}$ ditolak yang menunjukkan adanya pengaruh model pembelajaran advanced organizer terhadap kemampuan berpikir kreatif peserta didik.
\end{abstract}

C 2019 Unit Riset dan Publikasi Ilmiah FTK UIN Raden Intan Lampung

Kata kunci : advanced organizer, model pembelajaran, kemampuan berpikir kreatif

\section{PENDAHULUAN}

Pendidikan tidak lepas dari seorang pendidik. Pendidik tidak hanya dituntut untuk memberikan konsep materi kepada peserta didik lalu dihapalkan tetapi yang lebih ditekankan adalah bagaimana konsep-konsep itu dapat bertahan lama, sehingga dapat mempermudah proses belajar peserta didik (Bulkis, Muh, and Aisyah 2014). Belajar adalah suatu proses yang dilalui peserta didik untuk memperoleh pengalaman baru. Melalui mengalami atau latihan (Diani, Yuberti, and Syafitri 2016).

Model pembelajaran merupakan bagian menarik untuk meningkatkan kemampuan kognitif peserta didik. Model pembelajaran dapat dianggap sebagai hal yang penting dalam pembelajaran untuk menyediakan struktur serta arah dalam mengajar(Gidena and Gebeyehu 2017). Model pembelajaran secara langsung berpengaruh terhadap aktivitas, perilaku dan hasil belajar peserta didik, sehingga pemilihan model di 
sesuaikan dengan tingkat kemampuan, perkembangan dan psikologi peserta didik, hal ini bertujuan agar peserta didik berinteraksi dengan model pembelajaran yang ada(Ananto hidayah 2016).

Model pembelajaran bersifat memperkuat dorongan internal peserta didik untuk memahami ilmu, dengan cara menggali dan mengorganisasi data, menemukan adanya masalah dan mengupayakan untuk memecahkan masalah tersebut. Model pembelajaran dengan prinsip tersebut adalah model pembelajaran pengelolaan informasi. Salah satu bagian dari model pembelajaran ini adalah model pembelajaran advance organizer (Erlin maryani, Muchlis 2016).

Berpikir kreatif dicerminkan dalam empat aspek yaitu kefasihan atau kelancaran (fluency)dalam memberi jawaban masalah dengan tepat,keluwesan (flexibility) dalam memecahkanmasalah dengan berbagai cara, keaslian(originality) ide, cara, dan bahasa yangdigunakan dalam menjawab masalah, sertakemampuan elaborasi (elaboration) yaitumengembangkan, merinci, danmemperkaya suatu gagasan matematik.

Rendahnya kemampuaan berpikir kreatif diantaranya karena pembelajaran konvensional dengan metode ceramah yang masih mendominasi kegiatan belajar mengajar sehingga kegiatan proses belajar mengajar di dominasi oleh pendidik. Pendidik menyampaikan materi dan memberikan contoh soal tanpa melibatkan interaksi peserta didik atas pendapat dan analisanya, sehingga peserta didik berpikir dengan yang disampaikan oleh pendidik, yang menyebabkan kemampuan berpikir kreatif peserta didik kurang berkembang. Oleh karena itu perlu dikembangkan model mengajar yang melibatkan peserta didik lebih aktif dan mampu berpikir secara kreatif dalam proses belajar mengajar(Yenni and Putri 2017).
Berdasarkan hasil wawancara peneliti dengan narasumber sebagai guru IPA kelas VIII di SMP Negeri 33 Bandar Lampung menunjukkan bahwa proses pembelajaran yang diterapkan masih berpusat kepada pendidik yang hanya menggunakan media berupa buku LKS (Lembar Kerja Siswa), kemampuan peserta didik dalam berpikir kreatif juga sangat kurang diperhatikan. Kemampuan berpikir kreatif peserta didiknya, narasumber menjelaskan bahwa belum ada kegiatan yang dapat menumbuhkan kemampuan berpikir kreatif peserta didik, karena pada saat proses pembelajaran berlangsung, peserta didik lebih banyak duduk, diam ditempat dan mendengarkan guru yang aktif menjelaskan materi pembelajaran. Beda penelitian sebelumnya terletak pada kemampuan berpikir kreatif peserta didikdengan harapan model pembelajaranadvanced organizer mampu memberikan kemampuan peserta didik dalam berpikir kreatif.

\section{METODE PENELITIAN}

Penelitian ini menggunakan jenis Quasy Eksperiment Design dengan rancangan desain Non Equivalent Control Group Design. Penelitian menggunakan dua kelas sebagai kelas eksperimen dan kelas kontrol. Populasi penelitian adalah peserta didik kelas VII. Teknik pengambilan sampel yang digunakan dengan cara Cluster Random Sampling dengan sampel dari dua kelas yaitu kelas VII H sebagai kelas eksperimen dan kelas VII F sebagai kelas kontrol.

Teknik pengumpulan data menggunakan metode tes untuk melihat kemampuan berpikir kreatif peserta didik peserta didik dan metode wawancara untuk melihat permasalahan yang terjadi dalam pembelajaran di sekolah. Sebelum dilakukan analisis dilakukan uji normalitas dan uji homogenitas. Uji statistik 
Indonesian Journal of Science and Mathematics Education 02 (1) (2019) 79-83

Indra Gunawan dan Listia Ernaeni

Model Advanced Organizer:.....

menggunakan taraf signifikansi 5\%. Uji hipotesis yang dilakukan menggunakan uji t.

\section{HASIL DAN PEMBAHASAN}

Data penelitian meliputi data hasil tes pemahaman konsep. Tabel 1 Nilai kemampuan berpikir kreatif berdasarkan pembelajaran

Tabel 1. Nilai pemahaman konsep berdasarkan pembelajaran

\begin{tabular}{lccc}
\hline $\begin{array}{c}\text { Model } \\
\text { Pembelajaran }\end{array}$ & $\begin{array}{c}\text { Jumlah } \\
\text { Data }\end{array}$ & $\begin{array}{c}\text { Nilai } \\
\text { rata- } \\
\text { rata }\end{array}$ & $\begin{array}{c}\text { Nilai } \\
\text { Tertinggi }\end{array}$ \\
\hline $\begin{array}{l}\text { Advanced } \\
\text { Organizer } \\
\text { Konvensional }\end{array}$ & 28 & 65,67 & 88 \\
\hline
\end{tabular}

Berdasarkan tabel 1 menunjukkan bahwa nilai rata-rata tes kemampuan berpikir kreatif menggunakan model pembelajaran Advanced Organizer lebih tinggi dibandingkan menggunakan konvensional. Selanjutnya nilai tertinggi penggunaan model pembelajaran Advanced Organizer lebih tinggi dibandingkan pembelajaran konvensional.

Uji prasyarat analisis menggunakan uji normalitas menggunakan uji kolmogrovsmirnov dan uji homogenitas mengguanakan uji homogeneity of variances dengan bantuan program SPSS 17 dengan signifikansi sebesar $5 \%$. Berikut tabel hasil data uji normalitas dan homogenitas.

Tabel 3. Hasil uji normalitas

\begin{tabular}{|c|c|c|}
\hline Kelompok & Sig & Keterangan \\
\hline Eksperimen & 0,102 & Normal \\
\hline Kontrol & 0,182 & Normal \\
\hline \multicolumn{3}{|c|}{ Tabel 4. Hasil uji homogenitas } \\
\hline Kelompok & Sig & Keterangan \\
\hline Eksperimen & 0.085 & Homogen \\
\hline Kontrol & 0,085 & Homogen \\
\hline
\end{tabular}

Berdasarkan hasil data tersebut menunjukan bahwa data terdistribusi normal dan memilki variasi yang homogen. Sehingga pengujian hipotesis data menggunakan uji tsebagai berikut:

Tabel 5. Hasil Uji hipotesis

\begin{tabular}{|c|c|c|}
\hline $\begin{array}{c}\text { Hipotesis } \\
\text { Uji T }\end{array}$ & $\begin{array}{c}\text { Sifnifkansi } \\
\text { terhadap } \\
\text { Pemahama } \\
\text { n Konsep }\end{array}$ & $\begin{array}{c}\text { Keputusa } \\
\text { n Uji }\end{array}$ \\
\hline $\begin{array}{c}\text { Model } \\
\text { Pembelajar } \\
\text { an }\end{array}$ & $\begin{array}{c}0,044> \\
0,05\end{array}$ & $\begin{array}{c}\mathrm{H}_{0} \\
\text { Ditolak }\end{array}$ \\
\hline
\end{tabular}

Berdasarkan tabel 4.8 hasil uji hipotesis uji $\mathrm{t}$ dimana $\mathrm{H}_{0}$ ditolak menunjukkan bahwa ada pengaruh pembelajaran yang mendapatkan perlakuan model pembelajaran advanced organizer dengan pembelajaran konvensional.

Hasil tabel 1 nilai rata-rata peserta didik yang menggunakan model pembelajaran Advanced Organizer 65,67, sedangkan nilai rata-rata peserta didik yang menggunakan pembelajaran konvensional 59,13. Hal ini menunjukkan bahwa model pembelajaran Advanced Organizer dengan materi suhu dan perubahannya memudahkan peserta didik untuk memahami dan menguasai materi.

Pembelajaran di kelas eksperimen berjalan dengan baik walaupun dengan menggunakan model pembelajaran baru yang belum pernah digunakan oleh pendidik. Peserta didik menerima dengan senang hati dan merasa tidak kesulitan dalam proses pembelajaran, ini dibuktikan dengan kemampuan berpikir kreatif peserta didik dengan menggunakan model pembelajaran Advanced Organizer nilai rata-ratanya lebih tinggi dibandingkan dengan menggunakan pembelajaran konvensional.

Selanjutnya peserta didik dibantu oleh pendidik untuk mengamati fenomena yang terjadi dalam kehidupan sehari-hari dan 
membantu peserta didik untuk mengamati percobaan menggunakan powerpoint. Langkah ini adalah langkah pertama yaitu penyajian organizer. Peserta didik diarahkan dan dibimbing peneliti untuk mengamati dan melihat lembar kerja peserta didik.

Peneliti menyampaikan materi kepada peserta didik serta membangkitkan perhatian peserta didik agar terarah dengan pembelajaran kemudian peserta didik mengerjakan tugas-tugas yang terdapat dalam lembar kerja. Langkah ini adalah langkah kedua yakni menjelaskan materi dan tugastugas pembelajaran, dengan ini peserta didik mampu menjawab pertanyaan kemampuan dan pengetahuan. Langkah ketiga yakni memperkokoh pengorganisasian kognitif peserta didik dengan menggunakan prinsipprinsip rekonsilisasi terintegrasi serta peneliti meningkatkan keaktifan peserta didik didalam pembelajaran dan juga membangkitkan pemikiran kritis peserta didik terhadap pengetahuan.

Berbeda dengan kelas eksperimen, kelas kontrol menggunakan pembelajaran konvensional. Awal pembelajaran peneliti menjelaskan tujuan pembelajaran dan memberikan apersepsi pada materi suhu dan perubahannya. Selanjutnya peserta didik diberi kesempatan untuk membaca buku pada materi tersebut dan diberikan kesempatan untuk bertanya kepada peneliti terkait hal yang dibaca tersebut. Selanjutnya peserta didik berdiskusi dengan mengerjakan lembar kerja dan mempresentasikan hasil dari diskusi tersebut.

Pembelajaran menggunakan konvensional peserta didik jarang aktif dalam pembelajaran, kurangnya pengetahuan dan motivasi pada awal pembelajaran. Saat peserta didik menyelesaikan soal-soal pada lembar kerja hanya semata-mata untuk menyelesaikan tugas tersebut tanpa memahami materi tersebut. Sehingga peserta didik kurang dalam mendapatkan pengetahuan yang berdampak pada proses pembelajaran dan pemahaman yang rendah. Hal ini sesuai dengan riset yang dilakukan R.G hatika bahwa penggunaan model pembelajaran advanced organizer efektif meningkatkan hasil belajar peserta didik kelas eksperimen pada aspek kognitif, afektif dan psikomotorik secara signifikan(Hatika 2016).

Kesimpulan yang dapat diambil bahwa terdapat perbedaan pembelajaran advanced organizer dan konvensional. Sehingga pembelajaran menggunakan advanced organizer lebih efektif walaupun tidak signifikan dibandingkan dengan konvensional. Kemampuan berpikir kreatif kelas eksperimen menggunakan pembelajaran advanced organizer lebih tinggi dibandingkan dengan kelas kontrol yang menggunakan konvensional. Seperti halnya penelitian yang dilakukan Jahratun Mika secara keseluruhan pembelajaran advanced organizer dapat menjadi alternatif pilihan dalam proses belajar mengajar di kelas(Mika, Zainuddin, and An'nur 2014) sehingga dengan menggunakan model pembelajaran advanced organizer mampu meningkatkan kemampuan berpikir kreatif peserta didik juga.

Perbedaan dengan penelitian lain terletak pada variabel terfokus pada kemampuan berpikir kreatif, ini berarti penelitian yang dilakukan peneliti sesuai dengan penelitian sebelumnya. Pembelajaran advanced organizer dapat meningkatkan kemampuan berpikir kreatif peserta didik.

\section{KESIMPULAN}

Model pembelajaran advanced organizer lebih efektif digunakan dilihat dari data nilai yang diperoleh bahwa nilai rata-rata kemampuan berpikir kreatif kelas eksperimen yaitu 65,67 yang lebih 
signifikan dibandingkan dengan kelas kontrol yaitu 59,13, kemudian dari hasil uji independent sample t-test pada pada program SPSS 17.00 didapatkan hasil dari nilai sig 2tailed yaitu 0,04 , oleh karena nilai sig $<0,05$ maka $\mathrm{H}_{0}$ ditolak, jadi dapat disimpulkan dari penelitian yang telah dilakukan adalah terdapat pengaruh model pembelajaran advanced organizer terhadap kemampuan berpikir kreatif peserta didik materi suhu dan perubahannya di SMP Negeri 33 Bandar lampung.

\section{DAFTAR PUSTAKA}

Ananto hidayah, Yuberti. 2016. "Pengaruh Model Pembelajaran POE (Predict Observe Explain) Terhadap Keterampilan Proses Belajar Fisika Pokok Bahasan Suhu Dan Kalor." International Journal of Science and Mathematics Education 1(1):21-27.

Bulkis, Tawil Muh, and Azis Aisyah. 2014. "Penerapan Pendekatan Pembelajaran Advance Organizer Untuk Meningkatkan Keterampilan Berpikir Kritis Dan Pemahaman Konsep Fisika Pada Peserta Didik Kelas VIII Smp Negeri 1 Ma 'rang Kabupaten Pangkep." Jurnal Sains Dan Pendidikan Fisika 1(3):314-23.

Diani, Rahma, Yuberti Yuberti, and Shella Syafitri. 2016. "Uji Effect Size Model Pembelajaran Scramble Dengan Media Video Terhadap Hasil Belajar Fisika
Peserta Didik Kelas X MAN 1 Pesisir Barat." Jurnal Ilmiah Pendidikan Fisika Al-Biruni 5(2):265-75.

Erlin maryani, Muchlis, dan Jamaluddin. 2016. "Jurnal Penelitian Pendidikan IPA (JPPIPA)."Jurnal Penelitian Pendidikan IPA (JPPIPA) 2(1).

Gidena, Asay and Desta Gebeyehu. 2017.

"The Effectiveness of Advance Organiser Model on Students' Academic Achievement in Learning Work and Energy." International Journal of Science Education 39(16):1-14.

Hatika, R. G. 2016. "Peningkatan Hasil Belajar Fisika Dengan Menerapkan Model Pembelajaran Advance Organizer Berbantu Animasi Komputer." Jurnal Pendidikan Fisika Indonesia 12(2):13-117.

Mika, Jahratun, Zainuddin Zainuddin, and Syubhan An'nur. 2014. “Penerapan Model Pembelajaran Advance Organizer (AO) Untuk Meningkatkan Hasil Belajar Siswa." Berkala Ilmiah Pendidikan Fisika 2(3):222.

Yenni and Silvi Elya Putri. 2017. "Optimalisasi Kemampuan Berpikir Kreatif Matematis Siswa Smp Melalui Pembelajaran Everyone Is a Teacher Here.” Jurnal JNPM (Jurnal Nasional Pendidikan Matematika) 1(2):334. 